\title{
Prevalence and intensity of Trypanosoma sp. in wild swamp eels (Synbranchus bengalensis) marketed in Surabaya, Indonesia
}

\author{
GUNANTI MAHASRI ${ }^{1, \bullet}$, SETIAWAN KOESDARTO ${ }^{2}$, KISMIY ATI ${ }^{1}$, DESI P.W. SARI ${ }^{1}$, \\ MUHAMMAD B. SANTAMURTI ${ }^{1}$, IQYU W. KANDI ${ }^{3}$, SELVI D.S. FITRI ${ }^{3}$, MUHAMAD AMIN ${ }^{1}$ \\ ${ }^{1}$ Department of Fish Health Management and Aquaculture, Faculty of Fisheries and Marine, Universitas Airlangga. Kampus C Unair, Jl. Mulyorejo, \\ Surabaya 60115, East Java, Indonesia. Tel.: +62-31-5992785, Fax.: +62-31-5993015, ”email: gunanti.mahasri @ fpk.unair.ac.id \\ ${ }^{2}$ Department of Parasitology Veterinary, Faculty of Veterinary Medicine, Universitas Airlangga. Kampus C Unair, Jl. Mulyorejo, Surabaya 60115, East \\ Java, Indonesia \\ ${ }^{3}$ Program of Aquaculture, Faculty of Fisheries and Marine, Universitas Airlangga. Kampus C Unair, Jl. Mulyorejo, Surabaya 60115, East Java, Indonesia
}

Manuscript received: 5 July 2019. Revision accepted: 21 October 2019.

\begin{abstract}
Mahasri G, Koesdarto S, Kismiyati, Sari DPW, Santamurti MB, Kandi IW, Fitri SDS, Amin M. 2019. Prevalence and intensity of Trypanosoma sp. in wild swamp eels (Synbranchus bengalensis) marketed in Surabaya, Indonesia. Biodiversitas 20: $3262-3268$. Trypanosoma sp. is parasitic protozoa, which can infect not only aquatic organisms but also humans. As the parasite considered a zoonosis disease, there has been a lot of concern about the presence of this parasite in aquaculture commodities. This research aimed to detect and determine the prevalence and intensity of Trypanosoma sp. infection in wild-caught swamp eels (Synbranchus bengalensis) marketed in Surabaya. A total of sixty swamp eels with $47.30 \pm 4.69 \mathrm{~cm}$ in length were collected from two different locations, Ambengan and Karah, Surabaya, East Java, Indonesia. The swamp eels were transported alive in two aerated plastic bags to the laboratory. The observed parameters were prevalence and intensity of Trypanosoma sp. in the eels' blood, total erythrocyte counts and total differential leucocyte count (monocytes, lymphocytes, basophils, eosinophil, and neutrophil). The result showed that 7 of 30 (23\%) wild-caught swam eels obtained from Ambengan and 9 of 30 eels (30\%) collected from Karah were infected by Trypanosoma sp. The intensity of the parasite in eels collected from both locations was considered as moderate, 12.6 parasites/eel (Ambengan) and 5.9 parasites/eel (Karah). Additionally, hematology analysis indicated total erythrocytes count of blood in the infected eels from both locations were significantly lower than total erythrocytes of blood in the non-infected eels, $\mathrm{p}<0.05$. Furthermore, hematology analysis indicated that the numbers of monocyte, lymphocyte, and neutrophil were significantly different than that of non-infected eels, $\mathrm{P}<0.05$. Meanwhile, there was no significant difference in cell counts of basophils and eosinophil in the blood of infected and non-infected eels, $p>0,05$. These results demonstrate that swamp eels marketed in Surabaya were infected by Trypanosoma sp.
\end{abstract}

Keywords: Hematology, intensity, prevalence, swamp eels, Trypanosoma

\section{INTRODUCTION}

Swamp eel (Synbranchus bengalensis) is one of the economically important aquatic commodities in Indonesia. According to Astiana et al. (2015), eel contains $75.32 \%$ protein, $0.58 \%$ fat, and $22.54 \%$ carbohydrates, various minerals, vitamin A, iron, and omega 3. Due to the rich nutritional content, demand for the aquatic commodity in both domestic and abroad are pretty high. In 2012, the amount of eel exported to several countries, including Asia, Europe, Australia, and the United States reached 6.081 tons (BPS 2012; Manurung et al. 2015). Meanwhile, in the domestic market, the demand for eels is also high, 20 tons/year (Jakarta), 30 tons/year (Yogyakarta) (Syarif et al. 2017).

The swamp eels are generally inhabiting the muddy area with a lot of organic materials, $\mathrm{pH}$ of about 3,6- 6,5 (Welcomme, 1979). According to Prasetyo et al. (2004), environment with such acidic $\mathrm{pH}$ is generally inhabited by many opportunistic diseases, including parasites that infect aquatic organisms. One of the most common diseases found in the aquatic environment is parasitic protozoa, called Trypanosoma sp. The parasite has been previously reported to infect many species of aquatic organisms including catfish, goldfish, and wild swamp eels (Sriraj et al. 2019; Telipot and Darullman 2000). In addition, a study by Khati et al. (2014) reported that wild eels caught from swamps or rice fields in Riau District were infected by the parasitic protozoa. Shahi et al. (2013) reported that Trypanosoma mukasai infected freshwater fish (Trilophysa marmorata) in the Jhelum river, India. Ruszczyk et al. (2008) found Trypanosoma carassii causing $60-100 \%$ mortality in goldfish. Similarly, Leremenko et al. (2014) documented Trypanosoma sp. infected Carassius carassius and Esox lucius.

Trypanosoma-infected animals can cause death if the intensity and prevalence are high. Several studies reported that mortality of fish caused by the parasitic protozoa reached 50-65\% (Chong 2005). According to Chong, (2005), life cycle of trypanosome started as sphaeromastigotes in the digestive tract of leech and produce epimastigote that migrated to proboscis of the leech. Then, the espistigote transformed into metatrypanosoma, which was later inoculated into fish when the leech feeds on the fish. The infected fish then became lethargic, anemic, and emaciation. The main 
clinical symptoms of Trypanosoma sp. infected fish animals are decreasing in the number of erythrocyte cells, and an increase in the number of leucocyte cells as part of the animal's immune systems. Trypanosoma sp. enters the host's body, and the body's defense system will recognize parasites and stimulate lymphocytes to form antibodies to combat the pathogen (Gupta 2006).

Acknowledging its widely distributed in many important aquatic organisms, research to study the prevalence and intensity of the pathogen in wild swamp eels was very important. Thus, this research aimed to study the prevalence, intensity, and blood profiling of swamp eels (Synbranchus bengalensis) infected by Trypanosoma sp. This research result could be additional information about the current condition of swamp eels and status of the deathly disease in Surabaya region.

\section{MATERIALS AND METHODS}

\section{Samples}

A total of 60 swamp eels (Synbranchus bengalensis) with $47.30 \pm 4.69 \mathrm{~cm}$ in length were collected from two markets namely Ambengan, and Karah, Surabaya, East Java, Indonesia. The swamp eels were transported alive in two aerated plastic bags to the Laboratory of Fish Diseases, Faculty of Fisheries and Marine, Airlangga University, Surabaya. Arriving at the laboratory, the eels were reared in two different aquaria with the same water as where they were taken, and also equipped with aeration stones for supplying oxygen.

\section{Sample examination}

Blood was collected from the caudal vein of each eel using a syringe previously filled with ethylene diamine tetraacetic acid (EDTA) for an anticoagulant. Thereafter, the blood was immediately processed for blood smear on a glass slide and fixed with methanol for 3 minutes for drying. Then the blood smear was stained with Giemsa for 30 minutes, followed by rinsing with tap water (Prabowo 2009). The presence of Trypanosoma sp. in the blood smear was examined using a light microscope (Olympus CX23 LED) with 1,000x magnification and documented using a photomicroscope OptiLab. Trypanosoma sp. in blood was counted and identified based on its morphological features as well as characteristics of the hemiparasite according to Molina et al. (2016).

\section{Observed parameters}

\section{Prevalence and intensity}

Prevalence was defined as the percentage of eels infected by Trypanosoma sp., while the intensity was determined by looking at the total of parasite found in the eel's blood (Anshary 2008). The prevalence of a Trypanosoma sp. infecting the eels was calculated using this following formula:

$$
\text { Prevalence (\%) } \quad=\frac{\text { Total infected swamp eels }}{\text { Total examined swamp eels }} \times 100 \%
$$

While the intensity was calculated using a formula:

$$
\text { Intensity }(\text { indv } / \text { eel })=\frac{\text { Total parasites }}{\text { Total infected swamp eels }}
$$

\section{Total erythrocytes count (TEC)}

Total erythrocyte was counted according to a protocol developed by Blaxhall and Daisley (1973) with a slight modification. In brief, eel blood was collected from a vein using a $1 \mathrm{ml}$ syringe containing EDTA and placed into a microtube. Then $0.5 \mathrm{ml}$ of the blood mix was pipetted out with an RCB pipette and mixed with $\sim 100.5$ Hayem's fluid for diluting the blood. After being homogenized, the blood mix was pipetted out onto a Neubauer hemocytometer and covered with a coverslip. Then, the number of erythrocyte cells was counted using a microscope with 400 magnifications in 5 small block areas of the Neubauer hemocytometer. Afterward, the real total erythrocytes count was calculated using this formula:

Total Erythrocyte Counts $=\mathrm{n} \times 10^{4} \mathrm{cell} / \mathrm{mm}^{3}$.

Where, " $n$ " in the total number of Erythrocyte cells counted on the 5-block areas of the hemocytometer slide.

\section{Differential leucocyte counts}

The number of erythrocytes in the blood samples was calculated according to a protocol of Svobodova and Vykusova (1991). Briefly, eel blood was derived out from the caudal vein using a $1 \mathrm{ml}$ syringe containing EDTA as anticoagulant and stored in a microtube. Then, the blood was homogenized and dropped onto a glass object tip and spread until 2/3 of the slide area was covered. After drying, the blood-thinning slide was washed with $5 \%$ methanol for 3 min and followed by staining with $20 \%$ Giemsa for 20 minutes. Then, the slide was rinsed with water and airdried. The slide was then observed under a light microscope with a 1000x magnification. Furthermore, the differential leucocyte counts were calculated with a crosssectioned method, in which lymphocytes, monocytes, basophils, neutrophils, and eosinophils were counted and expressed as a percentage (Dalimunthe 2006).

\section{Data analysis}

The prevalence and intensity of Trypanosoma sp. were analyzed using a descriptive method. Meanwhile, total erythrocytes count and leucocytes between Trypanosoma sp. infected eels and non-infected eels were compared using independent-sample T-test, $\mathrm{p}<0.05$ according to Amin (2018).

\section{RESULTS AND DISCUSSION}

\section{Prevalence and intensity}

The result showed that seven out of 30 swamp eels collected from location 1 (Ambengan) and 9 of 30 swamp eels from location 2 (Karah) were infected by Trypanosoma sp. (Table 1). Morphologically, the parasite appears to have a flagellum, nucleus, and undulating 
membrane (Figure 1). Based on the observation result, the prevalence of Trypanosoma sp. in the swamp eels from Karah was $30 \%$, which was slightly higher than the prevalence in the swamp eels from Ambengan (23\%).

Based on the number, the calculated intensity of the parasite in the swamp eels from Ambengan was slightly higher compared to the swamp eels from Karah, Table 1.

\section{Total erythrocyte count}

Statistically, the TEC in the blood of Trypanosoma sp. infected eels was significantly lower than TCE in the blood of non-infected eels, $(\mathrm{t}=19.95$; df 58; $\mathrm{p}<0.01)$. Meanwhile, there was no significant difference in the TEC of Trypanosoma sp.infected eels between the 2 locations $(\mathrm{t}=0.99$, df 12, $\mathrm{p}=0.34)$. However, the TEC of blood from non-infected eels was significantly higher in the swamp eels collected from Ambengan than the swamp eels collected from Karah ( $t=3.25$, df 42, $\mathrm{p}=0.002)$.

\section{Differential leucocyte counts}

Total differential leucocyte counts or white blood cells (WBC) in the blood of Trypanosoma sp. - infected eels had the same pattern in both locations, in which the number of three WBC (monocyte, lymphocyte, and neutrophil) were significantly different than cell counts of the three cells in non-infected eels, $p<0.05$. Meanwhile, the number of the other two WBC cells (basophil and eosinophil) was not significantly different than those of non-infected eels, $p \geq 0.05$. Figure 2 presents the form of five white blood cells viewed under a light microscope.

The monocyte counts of the swamp eels infected by Trypanosoma sp. were significantly higher than monocyte counts in non-infected weels, $(t=5.66$, df 19 , $\mathrm{p}<0.01)$. Additionally, the number of lymphocyte in the blood of the infected eel was significantly lower than lymphocyte counts in non-infected eels, $(\mathrm{t}=3.5$ df 18 , $\mathrm{t}=0002)$. Also, the neutrophil count of the infected eels was significantly higher than that of non-infected eels $(\mathrm{t}=2.8 \mathrm{df}$ $20, \mathrm{p}=0.01)$. Table 3 presented the average number of monocyte, basophil, and eosinophil in the blood of Trypanosoma-infected eels and non-infected eels.

Meanwhile, basophil and eosinophil of blood-derived from the swamp eels infected by Trypanosoma sp. in both locations was not significantly different from that of noninfected eels $(\mathrm{t}=1.12$, df $37 \mathrm{p}=0.28)$ and $(\mathrm{t}=0.67 \mathrm{df} 37$, $\mathrm{p}=0.51$ ) for basophil and eosinophil respectively, Table 3 .
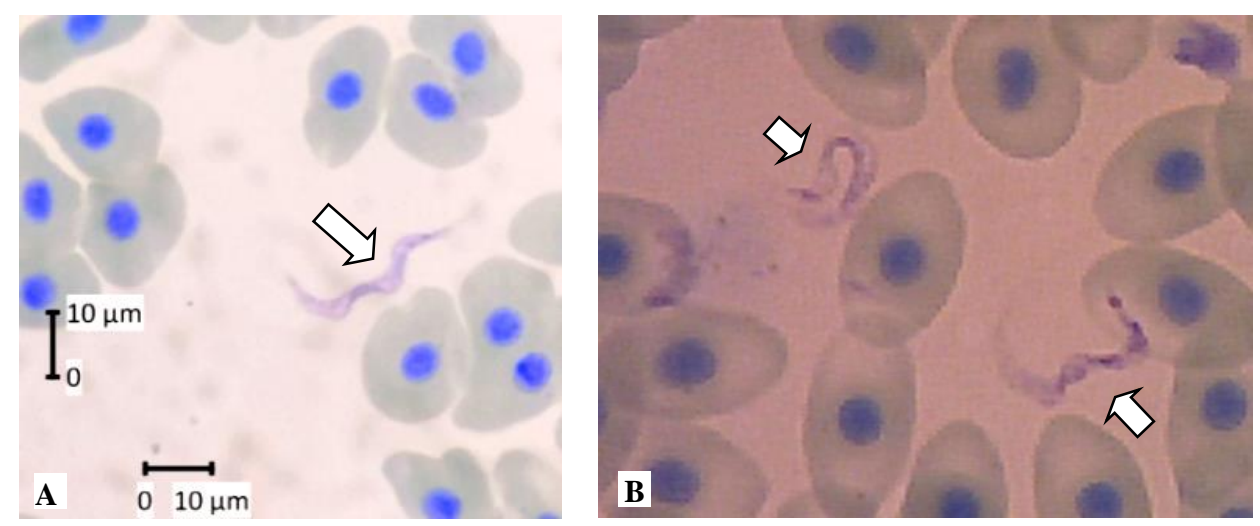

Figure 1. Trypanosoma sp. in blood smear of swamp eels collected from two markets (Ambengan dan Karah), Surabaya, East Java, Indonesia viewed under a light microscope with 1,000x magnification.

Table 1. The prevalence, intensity of Trypanosoma sp. in the swamp ells marketed in the Surabaya, Indonesia

\begin{tabular}{lccccc}
\hline \multicolumn{1}{c}{ Location } & $\begin{array}{c}\text { The number of } \\
\text { samples (swamp eels) }\end{array}$ & $\begin{array}{c}\text { The total number of swamp eels } \\
\text { infected Trypanosoma sp. }\end{array}$ & $\begin{array}{c}\text { Total } \\
\text { Trypanosoma } \\
\text { sp. }\end{array}$ & $\begin{array}{c}\text { Prevalence } \\
\text { (\%) }\end{array}$ & $\begin{array}{c}\text { Intensity } \\
\text { (individuals/eel) }\end{array}$ \\
\hline I (Ambengan) & 30 & 7 & 88 & 23.3 & 12.57 \\
II (Karah) & 30 & 9 & 53 & 30 & 5.88 \\
\hline
\end{tabular}

Table 2. Total erythrocyte counts of the swamp eels infected by Trypanosoma sp. and non-infected swamp eels. Values are the averages of TEC with standard deviations

\begin{tabular}{lcc}
\hline $\begin{array}{l}\text { Sampling } \\
\text { location }\end{array}$ & $\begin{array}{c}\text { The Average of erythrocyte count in the blood of } \\
\text { Trypanosoma } \text { sp. infected eels }\left(\mathbf{c e l l s} / \mathbf{m m}^{\mathbf{3}}\right)\end{array}$ & $\begin{array}{c}\text { The Average of erythrocyte count in the blood of } \\
\text { noninfected eels }\left(\text { cells } / \mathbf{m m}^{\mathbf{3}}\right)\end{array}$ \\
\hline I (Ambengan) & $7.7 \times 10^{5} \pm 4.8 \times 10^{4 \mathbf{a}}$ & $1.34 \times 10^{6} \pm 9.5 \times 10^{4} \mathbf{c}$ \\
II (Karah) & $8.0 \times 10^{5} \pm 9.2 \times 10^{4}$ & $1.26 \times 10^{6} \pm 6.7 \times 10^{4} \mathbf{b}$ \\
\hline
\end{tabular}

Note: Different manuscript (a,b,c) indicates that there was significant difference in the average values, $\mathrm{p}<0.05$. 
Table 3. Differential leucocyte counts (monocyte, basophil, and eosinophil, lymphocyte, and neutrophil) of swamp eels infected by Trypanosoma sp. Values are the averages with standard deviations

\begin{tabular}{llccccc}
\hline \multicolumn{1}{c}{ Location } & \multicolumn{1}{c}{$\begin{array}{c}\text { Sample status } \\
\text { (infection/non-infection) }\end{array}$} & $\begin{array}{c}\text { Monocyte } \\
(\boldsymbol{\%})\end{array}$ & $\begin{array}{c}\text { Lymphocyte } \\
(\boldsymbol{\%})\end{array}$ & $\begin{array}{c}\text { Basophil } \\
(\boldsymbol{\%})\end{array}$ & $\begin{array}{c}\text { Eosinophil } \\
(\boldsymbol{\%})\end{array}$ & $\begin{array}{c}\text { Neutrophil } \\
(\boldsymbol{\%})\end{array}$ \\
\hline I (Ambengan) & Swamp eel infected by & $6.88 \pm 2.35$ & $83.63 \pm 5.48$ & $2.29 \pm 0.81$ & $1.21 \pm 0.59$ & $6.00 \pm 2.5$ \\
II (Karah) & Trypanosoma sp. & $8.56 \pm 2.01$ & $79.89 \pm 4.54$ & $2.33 \pm 0.87$ & $1.33 \pm 0.50$ & $7.78 \pm 2.28$ \\
I (Ambengan) & Swamp eels & $5.17 \pm 0.98$ & $85.74 \pm 2.28$ & $2.61 \pm 0.72$ & $1.26 \pm 0.45$ & $5.22 \pm 1.41$ \\
II (Karah) & with no infection & $6.80 \pm 0.81$ & $83.50 \pm 1.69$ & $2.10 \pm 0.79$ & $1.50 \pm 0.68$ & $5.90 \pm 1.07$ \\
\hline
\end{tabular}

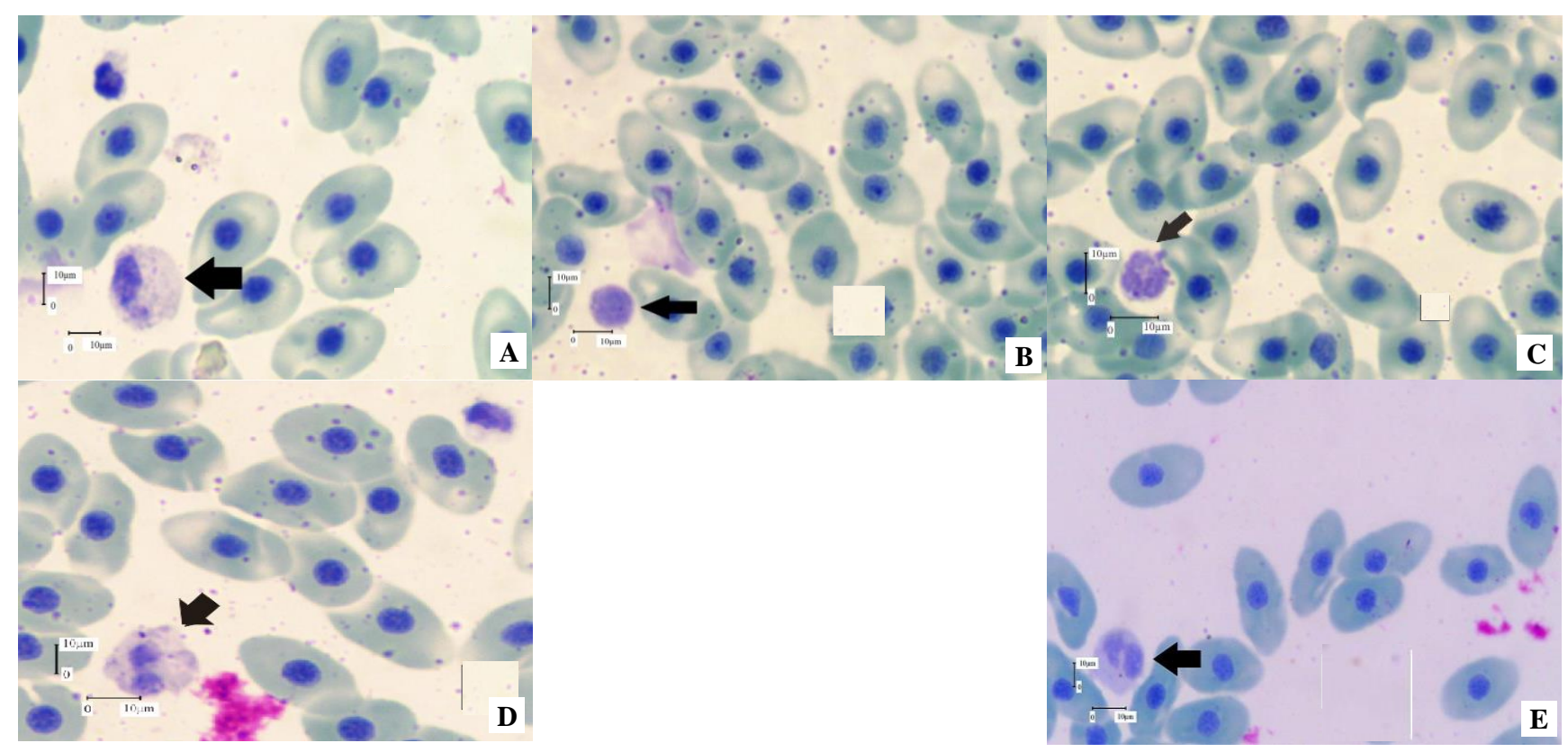

Figure 2. Differential leucocyte cells viewed under a light microscope at 1.000x magnification. Note: A. Monocyte, B. Lymphocyte, C. Basophil, D. Eosinophil, E. Neutrophil

A

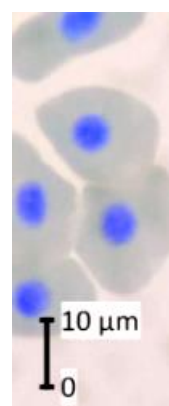

$0 \quad 10 \mu \mathrm{m}$
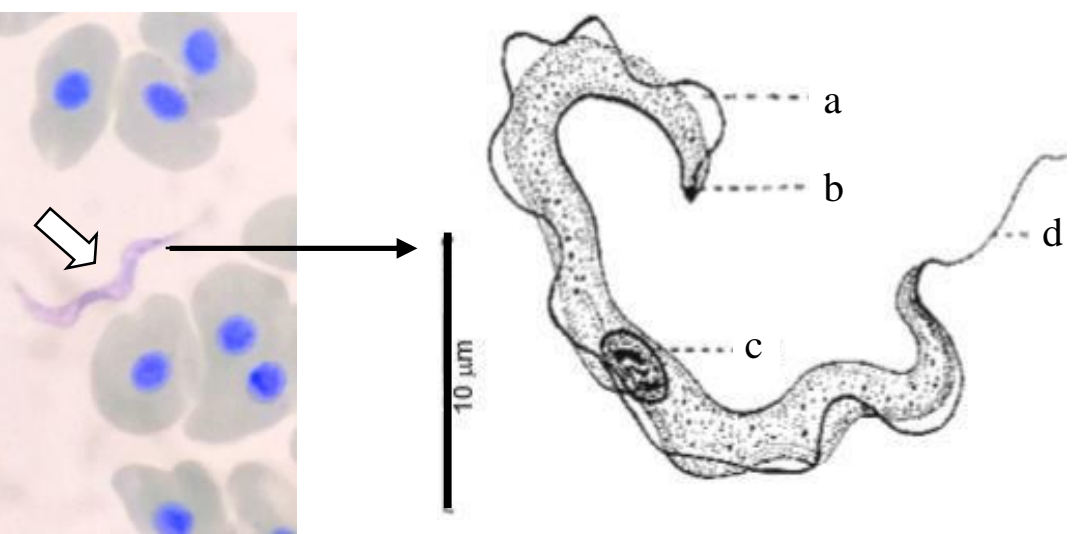

Figure 3. A. Trypanosoma sp., B. Morfologi of Trypanosoma and its organs (a. undulating membrane; b. kinetoplast; c. nucleus; d. Flagella) taken from (Gupta 2006).

\section{Discussion}

Trypanosoma sp. is a parasitic protozoan that can cause high mortality (50-65\%) in aquatic organisms Chong, (2005). This present study reported the detection of Trypanosoma sp. in the blood of swamp eels marketed in
Surabaya. The presence of Trypanosoma sp. in the eel's blood was observed under a LED microscope with 1000x magnification Whole-body part of Trypanosoma sp. were presented in Figure 3. 


\section{Prevalence and intensity}

The prevalence of Trypanosoma sp. in the swamp eels collected from Karah was 30\%, which was slightly higher than the prevalence in the swamp eels from Ambengan (23\%). The prevalence value of Trypanosoma sp. in the swamp eels from Karah was considered as "common" in Karah since its value at a range of $30-49 \%$ (Williams and Bunkley-Williams 1996). Meanwhile, the prevalence of Trypanosoma sp. in the eels from Ambengan was considered as "often" since its value at a range of 10-29\% (Williams and Bunkley-Williams 1996).

While the intensity of Trypanosoma sp. was considered as "often" in the swamp ells from Ambengan since its value was at a range of 10-19 individuals/eels and "occasionally" for the swamp eels collected from Karah since its value ranges from 1-9 individuals/eel (Williams and Bunkley-Williams 1996).

\section{Total erythrocytes count (TEC)}

Total erythrocytes count (TEC) of the swamp eel infected by Trypanosoma sp. in both sampling groups was $7.7 \times 10^{5} \pm 4.8 \times 10^{4}$ cells $/ \mathrm{mm}^{3}$ from Ambengan and 8.0 $\mathrm{x} 10^{5} \pm 9.2 \times 10^{4} \mathrm{cells} / \mathrm{mm}^{3}$ for Karah. These numbers are considered below normal conditions for healthy aquatic species $\left(1.05 \times 10^{6}-3.0 \times 10^{6}\right.$ cells $\left./ \mathrm{mm}^{3}\right)$ (Roberts 2012) (Table 5). This result indicates that the swamp eel was suffering from anemia. According to Wedemeyer and Yatsuke (1977), TEC of an aquatic organism, which is below normal count, is a symptom of anemia. Another study by Islam and Woo (1991) explained that the low number of erythrocytes or red blood cells (RC) is caused by two mechanisms, (1) hemolytic and (2) hemodilution factors. In terms of hemolytic factor, Trypanosoma sp. produced toxins that later attached erythrocyte cells to cause hemolysis (Islam and Woo 1991). Similarly, Mbaya et al. (2012) documented that Trypanosoma sp. in the blood produced enzymes such as protease and neuraminidase which caused damage erythrocyte cell membranes and lead to lysis. In terms of hemodilution factor, Trypanosoma sp. increases blood volume during the peak phase of the parasite (Islam and Woo, 1991). Besides, Mbaya et al. (2012) said that Trypanosoma sp. can damage erythrocyte membranes by whipping flagella into the erythrocyte membrane.

\section{Differential leucocyte counts}

Leucocytes or white blood cells are cells of the immune system involving in protecting the body against infectious diseases. Leucocytes or white blood cells consist of five types which are monocyte, lymphocyte, basophil, eosinophil, and neutrophil. The change in the number of differential leukocyte count represents the health status of aquatic organisms (Sabatine et al. 2002). This present study also showed that three of leucocyte cells (monocyte, lymphocyte, and neutrophil) from the swamp eels infected by Trypanosoma sp. were significantly different from that of the non-infected eels. While the other two cells were not significantly different, this result confirms that blood compositions are changing as the organisms infected by a certain disease, the changing is part of the host immune system.

\section{Monocytes}

The monocyte counts of the swamp eels infected Trypanosoma sp. from both locations were generally higher than that of non-infected eels. According to Campbell and Ellis (2013), the monocyte counts of blood-derived from both samples were all above normal levels in which a normal leucocyte count should be at $<5 \%$. The increase in the percentage of monocytes might indicate that the immune system is working against the parasitic infection through phagocytosis since monocyte function is to attack and break down pathogen that enters the body (Affandi and Tang 2002).

\section{Lymphocytes}

Lymphocytes are a type of WBC which produce antibody, a specific immune system against invading pathogens (Fujaya 2002). According to Salasia et al. (2001), lymphocyte counts for healthy aquatic organisms are between 65 to $86 \%$. Since the lymphocytes counts of the swamp eels infected by Trypanosoma sp. in both locations were still in the range of that value, it can be considered to be normal. The normal number of lymphocyte could be due to the degree of infection of Trypanosoma sp. in the eels collected from both locations wee in moderate.

Table 4. The prevalence, intensity of Trypanosoma sp. in the swamp ells marketed in the Surabaya, Indonesia

\begin{tabular}{lll}
\hline Sampling Location & $\begin{array}{l}\text { Prevalence } \\
(\%)\end{array}$ & $\begin{array}{l}\text { Intensity } \\
\text { (individuals/eel) }\end{array}$ \\
\hline I (Ambengan) & 23.3 & 12.57 \\
II (Karah) & 30 & 5.88 \\
\hline
\end{tabular}

Table 5. Total erythrocyte counts of the swamp eels infected by Trypanosoma sp. and total erythrocyte counts of ells being considered as normal.

\begin{tabular}{llll}
\hline Sampling Location & Total erythrocytes $\left(\right.$ cells $\left./ \mathbf{m m}^{\mathbf{3}}\right)$ & Degree of infection & Normal erythrocytes $($ Roberts 2012) \\
\hline I (Ambengan) & $7.7 \times 10^{5} \pm 4.8 \times 10^{4 \mathbf{a}}$ & Moderate & $1.05-3.0 \times 10^{6}$ cells $/ \mathrm{mm}^{3}$ \\
II (Karah) & $8.0 \times 10^{5} \pm 9.2 \times 10^{4} \mathbf{a}$ & Moderate & \\
\hline
\end{tabular}


Table 6. The results of differential leucocytes swamp eel infected Trypanosoma marketed in the Surabaya, Indonesia

\begin{tabular}{|c|c|c|c|c|c|c|c|}
\hline Location & $\begin{array}{l}\text { Total of swamp eel } \\
\text { infected by } \\
\text { Trypanosoma sp. }\end{array}$ & $\begin{array}{l}\text { Degree of } \\
\text { Infection }\end{array}$ & $\begin{array}{c}\text { Monocyte } \\
(\%)\end{array}$ & $\begin{array}{c}\text { Lymphocyte } \\
(\%)\end{array}$ & $\begin{array}{c}\text { Basophil } \\
(\%)\end{array}$ & $\begin{array}{c}\text { Eosinophil } \\
(\%)\end{array}$ & $\begin{array}{c}\text { Neutrophil } \\
(\%)\end{array}$ \\
\hline I (Ambengan) & 7 & Moderate & $6.88 \pm 2.35$ & $83.63 \pm 5.48$ & $2.29 \pm 0.81$ & $1.21 \pm 0.59$ & $6.00 \pm 2.5$ \\
\hline II (Karah) & 9 & Moderate & $8.56 \pm 2.01$ & $79.89 \pm 4.54$ & $2.33 \pm 0.87$ & $1.33 \pm 0.50$ & $7.78 \pm 2.28$ \\
\hline \multirow{3}{*}{\multicolumn{3}{|c|}{ Differential leucocyte counts for healthy eels }} & $<5$ & $65.20-86$ & $0.17-0.19$ & $0-1$ & $6-8$ \\
\hline & & & Campbell and & Salasia et al. & Affandi and & Svobodova & Roberts \\
\hline & & & Ellis (2013) & $(2001)$ & Tang (2002) & $\begin{array}{l}\text { and Vykusova } \\
\text { (1991) }\end{array}$ & $(2012)$ \\
\hline
\end{tabular}

\section{Basophils}

Basophil is functioning as cells which give alert to the body for any infection, and also produce chemical into the bloodstream to combat pathogen (Scobodova and Vykusova 1991). According to Tang (2002), the number of basophils in the blood of healthy eel was from 0.17 to $0.19 \%$. Another study described that basophil of healthy fell in a range of 0-0.5\% (Scobodova and Vykusova 1991). The present study showed that the average basophils of blood from the swamp eels infected by Trypanosoma sp. in both locations was 2.2\% (Ambengan), and 2.3\% (Karah). These numbers were considered to be higher than that of normal conditions, and the higher number of basophils might relate to the presence of infections caused by the parasite (Santoso et al. 2013).

\section{Eosinophil}

An eosinophil is a type of white blood cell that is responsible for parasite infection. According to Svobodova and Vykusova (1991), an average percentage of eosinophils in heathy fish fell between 0 to $1 \%$. The average eosinophil obtained in the present study from swamp eels infected by Trypanosoma sp. in both locations was $1.4 \%$ (eels from Ambengan), and $1.3 \%$ in eels from Karah, which was higher than eosinophil in healthy aquatic animal $(0-1 \%)$ (Table 6). The higher number of eosinophils indicates the presence of infection caused by the parasitic protozoa, Trypanosoma sp. because of eosinophil attacks and breaks down parasite by producing lysozyme enzymes in phagolysosomes (Effendi 2003; Rahma et al. 2015).

Both numbers of basophil and eosinophils were not significantly different in the blood of those infected eels and those of non-infected eels. Theoretically, the number of basophil and eosinophils in the blood of infected eels should be higher than those in non-infected eels. However, the number of basophils and eosinophils in both animal groups were higher than the normal (Affandi and Tang 2002; Svobodova and Vykusova, 1991). This could be due to the non-infected eels were infected by other types of pathogens such as bacteria or other parasites. Nevertheless, this speculative reason should be further studied.

\section{Neutrophils}

A neutrophil is part of the immune system, which specifically combats pathogen infection from bacteria or fungi (Saad et al. 2017). According to Roberts (2012), total neutrophils in the blood of the healthy eels range in 6-8\%.
Percentage of eosinophil obtained in the blood of eel infected by the parasitic protozoa was $6.8 \%$ (sample from Ambengan), and $7.7 \%$ in the samples from Karah. These values could be considered in normal, as the percentages were still in 6-8\%. These number was caused by the working mechanism of neutrophil which is combat pathogen infections from bacteria or fungi (Palmer et al. 2016).

In summary, the wild-caught swam eels obtained from Ambengan and Karah were infected by Trypanosoma sp. The intensity of the parasite in eels collected from both locations was considered as moderate, 12.6 parasites/eel (Ambengan) and 5.9 parasites/eel (Karah). Additionally, hematology analysis indicated total erythrocytes count of blood in the infected eels from both locations were significantly lower than total erythrocytes of blood in the non-infected eels, $\mathrm{p}<0.05$. Furthermore, hematology analysis indicated that the numbers of monocyte, lymphocyte, and neutrophil were significantly different than that of non-infected eels, $\mathrm{P}<0.05$. Meanwhile, there was no significant difference in cell counts of basophils and eosinophil in the blood of infected and non-infected eels, $p>0,05$. These results demonstrate that swamp eels marketed in Surabaya were infected by Trypanosoma sp.

\section{ACKNOWLEDGEMENTS}

We would like to thank all colleges who had helped this research especially from the laboratory of fish diseases, the Department of Fish Health Management and Aquaculture, Faculty of Fisheries and Marine, Universitas Airlangga, Surabaya, Indonesia.

\section{REFERENCES}

Affandi R, Tang UM. 2002. Animal Physiology Aquatic. Universitas Riau Press, Pekanbaru, Riau. [Indonesian]

Amin M. 2018. Marine protease-producing bacterium and its potential use as an abalone probiont. Aquacul Rep 12: 30-35

Anshary H. 2008. Learning Module Based on Student Center Learning (SCL) Courses in Fish Parasitology. Lembaga Kajian dan Pengembangan Pendidikan (LKPP). Universitas Hasanuddin. Makassar. [Indonesian]

Astiana I, Nurjanah, Suwandi R, Suryani AA, Hidayat T. 2015. Effect of rice field eel frying (Monopterus albus) on the composition of amino acids, fatty acids, cholesterol, and minerals. Depik Jurnal Ilmu-Ilmu Perairan, Pesisir dan Perikanan 4 (1): 49-57. [Indonesian] 
Blaxhall, P. C. and K. W. Daisley. 1973. Routine haematological methods for use with fish blood. J Fish Biol 5 (6): 771-781.

Campbell TW, Ellis CK. 2013. Avian and Exotic Animal Hematology, Blackwell Publishing. Iowa. pp. 53.

Chong R (2005) Trypanosomiasis in cultured Epinephelus areolatus Bull Eur Ass Fish Pathol 25: 32

Dalimunthe, S. 2006. Practical Guide to Parasites and Laboratory Fish Diseases Parasites and Fish Diseases. Fakultas Perikanan. Universitas Brawijaya. Malang. [Indonesian]

Fujaya Y. 2002. Fish Physiology: Basic Development of Fisheries Technology. Direktorat Jendral Pendidikan Tinggi Depdiknas. Jakarta. [Indonesian]

Gupta N. 2006. Historical Review of Piscine Trypanosomiasis and Survey of Indian Trypanosoma. Parasit Dis 30 (2): 101-115.

Islam AKMN, Woo PTK. 1991. Anemia And Its Mechanism In Goldfish Carassius auratus Infected With Trypanosoma danilewskyi. Dis Aquat Org 11: 37-43.

Khati SA, Mahatma R, Windarti. 2014. Parasites in the rice eel (Monopterus albus Zuiew, 1793) in Sawah Village, North Kampar District. Jurnal Online Mahasiswa Fakultas Matematika dan Ilmu Pengetahuan Alam Universitas Riau 1 (2): 1-13. [Indonesian]

Leremenko AG, Losev A, Kostygov AY, Lukes J, Yurchenko V. 2014 High Prevalence of Trypanosome Co-Infections in Freshwater Fishes. Folia Parasit 61(6): 495-504.

Manurung FR, Yusni E, Lesmana I. 2015. Effect of different feed on the growth of swamp eel (Monopterus albus) culture in plastic drum. Aquacoastmarine 6 (1): 13. [Indonesian]

Mbaya A, Kumshe H, Nwosu CO. 2012. The mechanisms of anemia in trypanosomosis: A review. Intech, Rijeka, Croatia.

Molina JP, Madi RR, Solferini VV, Ceccarelli PS, Pinheiro HP, Ueta MT. 2016. Trypanosomatids (Protozoa: Kinetoplastida) in three species of armored catfish from Mogi-Guaçu River, Pirassununga, Sao Paulo, Brazil. Brazilian J Vet Parasitol 25 (2): 131-141.

Palmer LJ, Damgaard C, Holmstrup P, Nielsen CH. 2016. Influence of complement on neutrophil extracellular trap release induced by bacteria. J Periodontal Res 51 (1): 70-76.

Prabowo MA. 2009. Overview of Goldfish Blood Leukocytes (Carassius auratus) after Infestation of Argulus japonicus. [Thesis]. Faculty of Fisheries and Marine. Airlangga University, Surabaya. [Indonesian]

Prasetyo BH, Adiningsih JS, Kusbagyono K, Simanungkalit. 2004. Mineralogi, Kimia, Fisika, dan Biologi Lahan Sawah. Tanah Sawah dan Teknologi Pengelolaannya. Balai Penelitian dan Pengembangan Pertanian Kementerian Pertanian, Jakarta. [Indonesian]

Rahma FW, Mahasri G, Surmartiwi L. 2015. Effect of Sargassum sp extract on erythrocyte amount and leukocytes differential in catfish (Clarias gariepinus). Jurnal Ilmiah Perikanan dan Kelautan 7 (2): 213-217. [Indonesian]

Roberts RJ. 2012. Fish Pathology. Wiley-Blackwell, Iowa.

Ruszczyk A, Joerink M, Guldenaar C, Hermsen, Savelkoul HF, Wiegertjes GF. 2008. cDNA expression library screening and identification of two novel antigens: Ubiquitin and receptor for
Activated C kinase (RACK) homologue, of the fish parasite Trypanosoma carassii. Fish Shellfish Immun 25: 84-90.

Saad M, Mahasri G, Satyantini WH. 2017. Production of carp Immunoglobulin-M exposed with whole protein from Myxobolus koi spore through feed as an immunostimulant. $1^{\text {st }}$ International Conference Postgraduate School Universitas Airlangga: "Implementation of Climate Change Agreement to Meet Sustainable Development Goals" (ICPSUAS 2017). Atlantis Press. Surabaya

Sabatine MS, Morrow DA, Cannon CP, Murphy SA, Demopoulos LA, DiBattiste PM, McCabe CH, Braunwald E, Gibson CM. 2002. Relationship between baseline white blood cell count and degree of coronary artery disease and mortality in patients with acute coronary syndromes: a TACTICS-TIMI 18 (Treat angina with aggrastat and determine cost of therapy with an invasive or conservative strategythrombolysis in myocardial infarction 18 trial) substudy. J Am Coll Cardiol 40: 1761-1768.

Salasia SIO, Sulanjari D, Ratnawati A. 2001. Hematology study of freshwater fish. Biologi 2 (12): 710-723. [Indonesian]

Santoso BB, Basuki F, Hastuti S. 2013. Analysis of body resistance hybrid Nila Larasati (Oreochromis niloticus) generation 5 (F5) infected by Streptococcus agalactiae bacteria with different concentrations. J Aquacult Manag Technol 2 (3): 64-75. [Indonesian]

Shahi N, Yousuf AR, Rather MI, Ahmad F, Yaseen T. 2013. First report of blood parasites in fishes from Kashmir and their effect on the haematological profile. Open Vet J 3 (2): 89-95.

Sriraj P, Pumhirunroj B, Wai A P, Sripan P, Boonmars T, Aukkanimart R, Songsri J, Boueroy P, Boonjaraspinyo S and Khueangchaingkhwang S. 2019) Seasonal variation of parasitic infections in Asian swamp eels from local markets in Yangon, Myanmar. Vet Integr Sci 17: 181193.

Svobodova Z, Vykusova B. 1991. Diagnostic and Prevention and Therapy of Fish Disease and Intoxication. Research Institute of Fish Culture and Hydrobiology Vodnany, Czechoslovakia.

Syarif AF, Soelistyowati DT, Affandi R. 2017. The phenotype diversity of three populations of Asian swamp eel Monopterus albus (Zuiew 1793) from West Java and biometric response on salinity. Jurnal Iktiologi Indonesia 16 (2): 133-143. [Indonesian]

Telipot M, Darullman T. 2000. In-vitro Cultivation of Trypanosoma sp. of eel, Monopterus albus, Institute of Oceanography College University Science and Technology Malaysia (KUSTEM), Malaysia.

Wedemeyer GA, Yatsuke WT. 1977. Clinical Methods For Assessment of The Effects of Environmental Stress or Fish Health. Technical Paper of The US Fish and Wildlife Service, Washington DC.

Welcomme RL. 1979. Fisheries Ecology of Floodplain Rivers. Longman Inc. New York.

Williams JEH, Williams LB. 1996. Parasites of Offshore Big Game Fishes of Puerto Rico and the Western Atlantic. Sportfish Disease Project Department of Marine Sciences and Department of Biology, University of Puerto Rico.

Yuningsih HD, Soedarsono P, Anggoro S. 2014. Relationship between organic material and aquatic productivity in hyacinth cover areas, open ater and floating net cages in Rawa Pening Semarang District, Central Java. Manag Aquat Resour J 3(1): 37-43. [Indonesian] 